\section{The American Geophysical Union Awards}

Three Awards have recently been announced by the American Geophysical Union.

Dr. M. A. Tuve

DR. M. A. Tuve, director of Carnegie Institution of Washington's Department of Terrestrial Magnetism, has beon awarded the twenty-fifth William Bowie Medal "for unselfish co-operation in research". Dr. Tuve has recently been concerned with the completion of arrangements for tho installation of a $30-\mathrm{m}$ radio telescope with multichannel hydrogen-line receiver, high in the Andes near La Plata, Argentina. Dr. Tuve is well known for his work on the application of electronies to geophysics, and his contributions to this field were of the greatest importance in the development of the cyclotron, ionosphere probes, and radar.

Prof. J. A. Van Allen

Prof. J. A. VAN Allen, head of the Department of Physics and Astronomy of the State University of Iowa, has been nominated to receive the second annual John A. Fleming Award for original research in geomagnetism and aeronomy. He played a key part in the development of the Aerobee research rocket and was prominent in scientific planning for the International Geophysical Year. Especially noteworthy are his contributions to rocket and satellite techniques, his discovory of the radiation belts which bear his name, and his studies of the Earth's magnetic field.

\section{Dr. A. J. Dessler}

Dr. A. J. Desslere, of the Graduate Research Center of the Southwest in Dallas, has been awarded the second annual James B. Macelwane Award, given in recognition of outstanding contributions to the geophysical sciences by a young scientist. At the age of thirty-four his work on the complex problems of space has made him an acknowledged authority in the field, especially concerning geomagnetic variations and particle radiations. He was recently appointed chairman of the new Department of Space Scionce, Rice University, Houston.

\section{The 1963 Kimber Genetics Medal of the National} Academy of Sciences:

Dr. Curt Stern

Dr. CuRt Stern, professor of genetics and zoology in the University of California, has been awarded the 1963 Kimber Genetics Medal of the National Academy of Sciences, for his contributions to the understanding of the mechanism of heredity, and for his part in establishing the relevance of genetic studies to the practice of medicine. Dr. Stern was born on August 30, 1902, in Hamburg, Germany. After receiving a Ph.D. degree from the University of Berlin in 1923, he conducted research in the Kaiser Wilhelm Institute. Dr. Stern's early work on tho problem of the organization of the hereditary materials in Drosophila produced the first analysis of the genetic nature of the $Y$-chromosome. In 1931 he published the now classic work proving that genetic crossing-over, the occasional reassortment of normally grouped hereditary characters, actually involves the exchange of segments of chromosomes, a process that is observable under a microscope. His subsequent research has concerned problems of the developmental genetics of Drosophila (including studies on the localization of patterns of bristle distribution and on cell lineages), a field in which he is the recognized authority. He has also become increasingly interested in problems of human genetics, and in recent years has contributed important knowledge on such topics as $Y$-chromosome linkage, colour type in the American Negro, and the genetie basis of colour blindness. Dr. Stern's book, Human Genetics, translated into several languages, has been a principal factor in making genetics familiar to the medical profession and has stimulated the introduction of courses in genetics in the curricula of medical schools.

\section{The Ciba Foundation}

The report for 1962 of the Ciba Foundation for the Promotion of International Co-operation in Medical and Clinical Research records 481 visitors during the year from 33 countries. Two four-day symposia, two one-day study groups, two lectures in research on ageing, three discussion meetings and one dinner meeting for scientific discussion were arranged during the year, in addition to the annual lecture given by Sir Julian Huxley on November 26 on "The Future of Man: Evolutionary Aspects". This is being published in the symposium on "The Future of Man", and details of all these activities and of publications of the Foundation during the year are included with the report.

\section{The Institution of Civil Servants}

THe annual report of the National Executive Committee of the Institution of Civil Servants for 1962, published in State Service for April, is marked by sharp criticism and veiled hostility to the National Incomos Commission and to Government policy as set forth in the White Paper, Incomes Policy: the Next Step. There is also further criticism of the report of the Zuckerman Committee, the Institution disagreeing with the view that pure basic research is best carried out in the environment of a university and that it should seldom be the direct concerm of Government scientific organizations. The Institution strongly opposed the proposal to transfer to a university such established lines of basic research as are to be continued. Moreover, while the Institution welcomes the admission that objective basic research is as intellectually demanding as pure basie research, its comments on the recommendations of the report generally are disappointingly shortsighted and show little indication of a capacity to take wide and unprejudiced views.

\section{The Windscale Advanced Gas-cooled Reactor}

Atom for April 1963 contains a comprehensive article on the Windscale Advanced Gas-cooled Reactor which, besides outlining the programme for the reactor and its economic potential, predicting that unit cost of $0.4 d$. or even $0.35 d$. per $\mathrm{kWh}$ is achievable, includes technical notes on the reactor. These notes describe briefly the reactor and its major design features and design concepts, its constructional and experimental features at Windscale, as well as events during the past year and the utilization of the reactor. Further information on various aspects of the work is to be found in papers presented at a symposium sponsored by the British Nuclear Energy Society in London on March 14 and 15.

\section{Atomic Energy Review}

The first issue of Atomic Energy Review was published in January by the International Atomic Energy Agency at Vienna (1, No. 1. Pp. 152. Vienna: International Atomic Energy Agency; London: H.M.S.O. Annual subscription (4 issues): 210 Sch.; $60 \mathrm{~s}$. stg.; 40 N.F.; 10 dollars; 35 D.M. Single issues: $63 \mathrm{Sch} . ; 18 \mathrm{~s}$. stg.; 12 N.F.; 3 dollars; 10.50 D.M.). The foreword states that the Review will cover both theoretical and practical aspects of the peaceful uses of nuclear energy. It will publish papers on subjects that are of urgent interest or are developing rapidly and reviews of developments in the various branches of physical seience and technology of interest to nuclear energy, including the applications of radioisotopes in all fields, industrial, scientific and medical. There will also be summaries of conferences, reports on recent discoveries, notes on mootings, and bibliographical material. However, there are indications that the journal will concentrate on the publication of reviews. The majority of the first issue is devoted to three review papers: on the purification of reactor moderator-coolants; on special materials for reactor construction and their methods of fabrication; and on 